\author{
Urszula GRZEGA, PhD, Professor of the University of Economics in Katowice \\ The Faculty of Management, The University of Economics in Katowice \\ e-mail: ugrzega@ue.katowice.pl
}

DOI: 10.15290/oes.2018.02.92.15

\title{
MACROECONOMIC DETERMINANTS OF THE STANDARD OF LIVING - THEORETICAL CONSIDERATIONS
}

\begin{abstract}
Summary
The aim of this paper is to make reflections on the macroeconomic determinants of the standard of living. They serve as the presentation of selected issues in terms of their impact on the degree of satisfying the needs of the population. They lead to the conclusion that the standard of living is the result of the comprehensive impact of many determinants of diverse nature (both macro- and microeconomic). There are numerous cause-and-effect connections between these determinants, but it is assumed that economic macro-determinants have a primary character in comparison with other determinants. They shape the basic conditions of the functioning of consumption entities. Thus, they constitute a kind of economic background and starting point as regards meeting the needs of particular groups and the standard of living in general. Although their influence is significant, it is also defined as indirect, deferred in time, and difficult to measure.
\end{abstract}

Key words: standard of living, macroeconomic determinants

JEL: I31

\section{Introduction}

The concept of the standard of living has a both complex and interdisciplinary character. It occurs both in the scientific and common language. Owing to the multitude of areas where the concept is used, many definitions of the standard of living in the subject literature may be encountered. In this paper, the standard of living denotes the degree to which human needs are satisfied, which results from the consumption of material goods and services and from using the amenities of both the natural and social environment [Bywalec, Rudnicki, 1999, p. 26]. Research on the standard of living implies, in fact, an analysis of the degree to which human needs are satisfied. Needs constitute the core of the concept of 'the standard of living'. It is the degree to which they are felt and satisfied that has an impact on the diversification of the standard of living of entities [Chan Yin Fah, 2010, p. 145] ${ }^{1}$. 
The basic entities of the research on the standard of living are households and the total population of the country or other territorial unions, e.g. regional ones [Konsument i konsumpcja..., 2006, p. 108; Luszniewicz, 1972, p. 10]. When the research on the degree to which needs are satisfied is conducted by using subjective evaluations, the research may also include an individual consumer [Słaby, 2007, p. 107].

The standard of living is determined by a variety of conditions and factors of both an economic and non-economic character. The aim of the elaboration is to present the macroeconomic determinants of the standard of living of the population that may constitute a certain set of external objects, forces, factors, phenomena, trends, and processes that have an impact on the degree of satisfying needs. The impact is of a non-direct character, is difficult to measure, and is deferred in time. Macro conditionings of an economic character usually operate independently from the entities responsible for the standard of living. This group of determinants may include among others: the level and rate of economic growth, the system of organization and functioning of economic life, the national system and policy, the situation on the labor market, as well as "new" conditions including: economic transformation, globalization and integration processes, as well as the economic crisis.

\section{GDP as the determinant of the standard of living of the population}

There are various connections between the economic situation of the country and the standard of living of its population - they include the effects of delay, multiplying factors and the phenomena of substitution, complementarity, synergy, and leveling [Szopa, 1994, p. 5]. The state of an economy expressed by the level and rate of its economic growth is one of the determinants of the standard of living of the population of a certain country. Gross domestic product (GDP) means the value of goods and services created by production factors located in a certain country. When it is corrected using net income from property abroad, it is known as the gross national product (GNP) [Begg,

1 Scientific research on the standard of living of the population in Poland has been conducted for many years. It regards both methodological and analytical issues. The problem was tackled by numerous eminent and respected scientists, including, among others: A. Luszniewicz, L. Zienkowski, A. Zelias, L. Frąckiewicz, B. Szopa, Cz. Bywalec, T. Słaby and J. Kramer. The research conducted on an international scale is characterized by a particularly large range and variety. The research attaches much importance to methodological solutions. Analytical works, on the other hand, are limited to the selected elements of the standard of living of the entities living in particular countries and to comparative research conducted in a both temporal and spatial perspective. Research on the standard of living of population on an international scale was mostly the particular contribution of such scientists as: E. Erikson, A. Campbell, H. Noll, J. Stiglitz, A. Sen, J. Fitoussi, R. Veenhoven, D. Cvrlje and T. Coric. 
Fischer and Dornbusch 1999, p. 45]. Hence GNP is defined as the money stream of the total product of a certain national economy. It comprises consumption plus investment plus government spending on goods and services [Samuelson, Nordhaus, 1995, p. 170]. GNP reduced by the usage of the possessed resources of fixed capital in a certain time period (i.e. amortization) is known as the national income. The national income is defined as the net the national product has created in the economy. Essentially, these concepts constitute the same category comprised of two various perspectives. The national product is defined as the stream of products produced in one year, whereas the national income as the stream of incomes of households in the form of wages, pensions, profits, and interest [Nojszewska, 1995, p. 204].

A two-fold understanding of the aforementioned category contributes to the fact that its impact on the standard of living may be explained in two ways. Firstly, the national income considered as the sum of personal income after deducting the income tax and both social and health insurance rates becomes the sum of disposable income of the population that is earmarked, among others, for the purchase of consumption goods, services, and savings. The analysis of GDP from the perspective of expenditures means the sum of expenditures on individual and public consumption as well as the gross national investment and net export [Begg, Fischer and Dornbusch, 1999, p. 37]. The main element of GDP is the expenditure on individual consumption. Part of government expenditure finances social consumption. In total, it has an impact on the standard of living of the population. The relation between them is expressed by the extreme inclination to either consume or save [Berbeka, 2006, p. 38]. Secondly, the national income as the net national product, which is the sum of products produced in the economy, means a certain state of goods and services, i.e. measures for satisfying consumer needs. The higher it is, the better the possibilities for satisfying needs, and thus the higher the standard of living is. The stream of consumption goods and a part of investment goods that are (on a current basis) earmarked for the consumption sphere in a certain year informs of the level of satisfied needs within a certain period. Naturally, not all goods are used by the population on a current basis or entirely. Some of them are accumulated into resources and are consumed in later periods. Thus, the degree of satisfying needs within a certain period is the result of the current consumption of goods and services, the usage of some consumption goods accumulated in previous periods, and public consumption financed within the frameworks of public consumption [Bywalec, 1991, p. 46].

While analyzing the impact of GDP on the standard of living of the population, it is also recommended to analyze (apart from the level and rate of economic growth) the proportions of its division into consumption and savings (investments), and also the spatial and social layout of both creation and division. Within short time periods there is a conflict in the division of GDP into consumption and savings. The more is earmarked for investment, the less is 
allocated for current consumption and the other way round. Savings, i.e. in practice the outlays on investment, affect the standard of living in longer time periods. When they are planned properly, they have an impact on the improvement of the standard of living of the society in the future, which means at the same time that the reduction of current consumption in favor of investment may cause a lower level of satisfying the current needs of the population [Grzega, 2012, p. 37].

The advantage of economic growth is usually the improvement of the standard of living of the population. This happens, among others, owing to the general economic growth of entities, which results in a certain situation on the labor market. It regards employment growth and unemployment reduction which have an impact on the income situation of entities, the level and structure of consumption expenditures and, as a consequence, affects the degree of satisfying the needs of the population. Nevertheless, it needs emphasizing that the employment level in the country depends on many factors. Owing to this, the increase of GDP does not necessarily mean the reduction of unemployment in the country, which results, among others, from the possibility of transferring working positions to other countries, more mechanical types of production and service work. Such situations as the aforementioned ones (including the phenomenon of the lack of functional harmony between education and labor) may cause a temporary increase of unemployment in particular sectors of the economy in the conditions of the economic growth [Saget, 2000, p. 623; Pissarides, 2000, pp. 67-82]. The special importance of the growth of GDP is attributed to developing countries despite the fact that in the subject literature it is difficult to find empirical confirmation of this thesis [Kenny, 2005, pp. 1-19]. It is frequently believed that particularly poor countries require an increase of GDP in order to increase the prosperity of their citizens. However, in many cases the increase takes place as the result of shifting operations 'from the informal sector into the formal one', which may take place simultaneously with the loss of farming for one's own needs, problems with availability of food, greater inequality of incomes - particularly in poorly developed countries. In general, it does not contribute to the improvement of the standard of living of the population, which, in turn, does not necessarily point to the role of GDP in the general economic growth of these countries [Bergh, 2009, p. 117].

The main disadvantage of the high rate of the economic growth is environmental degradation. The increased usage of materials observed simultaneously with the growth of GDP leads to a decrease in the degree of satisfying basic human needs such as: serenity, clean air, or direct access to nature [Bergh, 2009, p. 117]. Other negative consequences of economic growth are the effects of consumptionism and materialism, including the deterioration of the state of physical and mental life, reduction of family life, social life, the reduction of recession, or addiction to shopping [Larsen, Sirgy and Wright, 1999, p. 75]. An entirely different issue that needs to be mentioned here is the answer to the following 
question: Is the growth of GDP in any way likely to make people happy? The answer to the question ought to be preceded by deciding whether the analyzed category may be considered as any indicator of happiness [Weil, 2005, pp. 508510]. The consequences of economic growth are connected also with the more visible inequalities of income in the society [Dietsch, 2005, pp. 106-113]. According to A. Ashley, the poorest $20 \%$ of the society probably does not meet a proportional share in the growth, whereas in the case of decrease, it is the poorest people who lose most [Ashley, 2008, pp. 333-338]. In the subject literature there are also presented opinions implying that systematic aspirations for the growth of GDP lead to excessive expenditures on private consumption and an insufficient degree of supplying public goods [ $\mathrm{Ng}, 2003, \mathrm{p} .307]$, which (despite the economic growth) may cause a deterioration of the standard of living of the population.

The lack of empirical evidence of the occurrence of clear relations between the growth of GDP and the standard of living may result in the conclusion that the improvement of the standard of living may take place also in the case of the permanent growth of GDP. In Poland, hitherto, attempts to analyze the correlation between the rate of economic growth and the standard of living of the population indicate insignificant links between these categories [Berbeka, 2006, p. 240]. Similar conclusions may be drawn on the basis of the results of foreign research, the authors of which indicate the lack of substantial (in terms of statistics) links between the discussed categories. Interestingly, the results of their calculations simultaneously point at serious and positive correlations between variables: GDP per capita, expected life expectancy and the gross enrolment index [Schuller, 2009, p. 89]. In general, the conclusions regarding the impact of GDP on the standard of living of the population are usually drawn rather on the basis of logical premises and scientific intuition than on the precise calculations of scientists.

To sum up, it needs emphasizing that it is becoming a more frequent practice to perceive the importance of economic growth as the chance for improving the standard of living of the poorest group in the population. The subject literature shows attempts to define the economic growth conducive to the poor. The economic growth that is favourable to the poor is defined as growth that ensures greater benefits for the poor than for other people. The pro-poor growth implies also the situation of growth where benefits are gained by the poor regardless of what the situation of people who are not poor is [Szarfenberg, 2012]. To achieve this, economic growth must be additionally supported by proper reforms related to public services that lead to the long-lasting improvement of the conditions of the human growth. Of particular importance is the fair way of offering basic public services such as education and health services because they are considered to be the main factors of social development which means the formation of an environment in which all society members may fully use their potential, live in accordance with their own principles, and have more possibilities to choose from [Son, 2010, pp. 1-42]. 


\section{The system of organizing economic life as well as the state political system}

The system of organizing economic life is connected with the state political system, therefore these conditionings are considered together.

Different conditions of shaping the standards of living of entities are shaped by a centrally planned economy, whereas entirely different conditions regard a market economy. In the latter case, competition is a particularly important factor that leads in a natural way to reducing the prices of consumption goods and services and improving their quality. Owing to the existence of the phenomenon of competition, the consumption entities have larger selection possibilities and freedom of consumption. A market economy creates proper conditions for better satisfaction of needs, but, at the same time, is conducive to phenomena that may reduce the consumption possibilities of selected population groups. It regards such phenomena as unemployment, poverty, and social injustice [Grzega, 2012, pp. 39-40]. More detailed analyses of this issue will be presented in the further part of the elaboration.

The system of state organization is also connected with the range of democracy in the country. The positive impact of democracy on the standard of living of the population is visible, among others, in the possibility to form associations, lay one's claims and rights, in the freedom of speech and action. There are opinions implying that, owing to their openness and tolerance, democratic societies have the tendency to support economic growth. M. Friedman claimed that the lack of democracy in a society has a negative impact on economic growth [Dietsch, 2005, p. 106].

In the analyzed group of conditionings, considerable importance is attached to such social services as: education, health, the housing industry, and social security. The role of the state and its authority are also crucial. The role of the state lies mainly in removing the defectiveness of the market and reducing its imperfections. The tasks of the state in the sphere of a market economy are reduced to three functions: redistribution, allocation, and stabilization [Nojszewska, 1995, p. 272]. The redistribution function of the state is related to the distribution of domestic product and general social wealth among society members; it involves activities that aim at reducing too large and socially unacceptable differences in terms of income and wealth and at offering aid to weaker social groups (e.g. elderly people or people suffering from various diseases). Hence, it comprises activities in the sphere of social security and others aiming at reducing inequalities in the society. Social policy tasks connected with reducing social inequalities, 'saving' the poorest, etc. are listed as the most important state duties within the framework of the redistribution function. Such activities are closely linked with improving the standard of living of the poorest groups of the society and are of particular importance in the conditions of the global economic crisis [Ravallion, 2012]. The allocation function implies activities resulting in better allocation of production resources and consumption goods, especially as 
regards public goods including: educational, medical, and cultural services. By means of realizing this function, the state attempts to foster effective management of entities, including those in the sphere of consumption. The stabilization function enables the state to normalize and counterbalance economic activity by means of preventing, among others, economic recession, unemployment, and excessive inflation that have a negative influence on the standard of living of the population. The state may realize the aforementioned functions by making use of a wide range of administrative instruments (commands, bans, conditions, regulations). Apart from administrative instruments the state also possesses economic, social, and financial instruments [Szulce, Mruk, 1989, p. 3].

\section{The situation on the labor market}

The situation on the labor market, which is measured by the number of active and passive workers, considerably determines the standard of living of the population. The demand for labor declared by employers, i.e. demand for labor, results from the socio-economic policy of the country and from the actions of various market entities. It is determined by many factors, including (among others) the demand for consumer goods and services.

The employment rate is the factor that affects the standard of living of the population in a proportional way. It defines the level of income of the employed workers. In the macro social scale it also affects the growth of funds for the social care system. The employment level in the country is one of the basic indicators of both the level and quality of life of the population. Apart from issues related to obtaining income by the population, what matters is also the problem related to ensuring a sense of stable employment and secure remuneration. It is connected with satisfying the need for security of the population, especially as regards the material security of families [Drobnic, Beham and Prag, 2010, pp. 205-225]. Labor also satisfies the social need related to identity, integration with a certain group, and society in general [Gallie, 2002, p. 96]. It constitutes a certain type of core activity in the social life of a country [Kalleberg, 2009, p. 12].

The factor that has an adverse effect on the standard of living is the unemployment rate. Apart from the relation between the number of unemployed people and the number of employed ones, what is also crucial is the duration of the unemployment period and the number of attempts to find a job [Browning, Crossley, 2001, pp. 1-23]. Their impact on the standard of living may be termed as inversely proportional. In general, a large number of unemployed people in the country has a negative impact on the economic situation of entities affected by this problem. It has a negative influence also on the population that is not affected by the problem of unemployment. In times of economic crisis even people who are capable of keeping their jobs and means of subsistence are worried about the socio-economic situation of the country. These worries 
regard both their personal situation and the situation of the people affected by the problem of unemployment [Eggers, Gaddy and Graham, 2006, p. 209; Tella, MacCulloch and Oswald 2001, p. 335]. Either the loss or the lack of a job may have numerous consequences of an economic and social type, hence, they require state involvement in the removal and reduction of the negative effect, e.g. by the activity undertaken by the national social care system. Apart from reducing the effects of unemployment and ensuring conditions for a higher employment level, the state's caretaking role comprises also issues related to job quality and the quality of the professional life of citizens, including those related to ensuring harmony between the abilities of employees and the needs of the labor market by means of providing access to proper training [Gallie, 2007, pp. 1-33]. The connection between the protective social policy of the state and an effective labor market is a necessary condition for preventing poverty, social inequalities, and pathologies resulting from the lack of labor - ultimately resulting in lowering the standard of living of the population. While assessing the influence of the situation on the labor market on the standard of living of the population, it is necessary to take into consideration also other factors connected with the labor market, such as: the organization of labor in the society, social dialogue and the involvement of employees in labor, the balance between the professional and personal life of citizens, as well as sex-based discrimination [Davoine, Erhel and Guergoat-Lariviere, 2008, p. 164; Royuela, Lopez-Tamayo and Surinach 2008, p. 401].

\section{5. 'New' economic conditions in Poland}

The 'new' macroeconomic conditions of the standard of living in Poland, i.e. conditions, the influence of which has become essential in the last three decades, include the processes of transformation, globalization, and integration, as well as the economic crisis.

Economic transformation is understood as activities aimed at creating conditions for the functioning of market entities that go beyond the sphere of 'social awareness', and thus go beyond the sphere of human attitudes and behaviors resulting from them [Bałtowski, Miszewski, 2006, p. 24]. It denotes the complete and radical change of the general conditions of management of all the entities and units [Jakóbik, 2000, p. 49]. This unprecedented process initiated in the middle of the year 1989 opened the way to the transformation of the economy, the functioning of which in accordance with the dominant rules had already become impossible. The main purpose of transformation in Poland was the increased competitiveness of the economy and (what is most important from the perspective of the presented deliberations) the stable growth improving the standard of living of the population [Kołodko, 1999, p. 136]. Transforming the Polish economy into a market economy, i.e. constituting the market function as the main regulating mechanism, comprised various activities including, 
among others: ownership transformations, the greater autonomy of economic entities, liberty in fixing prices, and creating conditions for competition [Belka, 2000, p. 16].

One of the consequences of the transformation of the Polish economy was the redistribution of income and wealth. Before the year 1989 the distribution of funds within the framework of the national product took place with the dominating share of the state, whereas after 1989 it was realized on the basis of market regulations, which to a large degree entailed transformations in the ownership structure and the functioning of the labor market in Poland. At that time, what mattered most for the changes in the standard of living of the population were both the abilities and/or possibilities that entities had in order to adjust to the new rules present on the market. In many cases it turned out to be particularly difficult to adjust entities to the conditions on the labor market. A vast majority of the Polish people could not take the chances offered by the market mechanism. There were various reasons for that. All of them contributed to the occurrence of previously unknown social phenomena that significantly lowered the standard of living of the people affected by them. It regarded mainly unemployment, poverty, incurring debt, overall apathy, and discouragement to undertake any economic activity. On the other hand, however, competition on the labor market stimulated enterprises and encouraged a part of the population to make attempts to improve their situation.

Another market that underwent a radical change in the period of economic transformation was the market of consumer goods and services. An abundant goods supply, which was related to the formation of the consumer market, created very good conditions for satisfying the needs of the population. However, greater freedom as regards the possibilities of satisfying needs was more than once limited by the income situation of the entities. An additional problem lay in the considerable reduction of the public offer that led to the necessity to earmark private funds for satisfying needs that had been previously financed using social funds.

Apart from transformation processes, the present image of the standard of living of the population in Poland has also been affected by the processes of globalization and integration.

Globalization of consumption, which is one of the dimensions of globalization of life in general, implies proliferation of either identical or similar consumption patterns on a supranational scale [Bywalec, 2007, p. 145]. These patterns are usually transferred from highly developed countries to those less developed ones. In such a perspective, globalization may be considered as the tendency to become similar and homogenous. It contributes, among others, to homogenization of the needs, requirements, and expectations of consumers.

The globalization of consumption is visible, among others, in the changes in the way of fulfilling both basic needs and needs of a higher level. Global trends in consumption significantly affect changes in the degree of satisfying the needs from selected groups, e.g. as regards providing food or material back-up. 
As a consequence, it leads to equalization and unification of both levels and ways of living of societies. The similarities in the degree of satisfying consumers' needs in various places in the world may be assessed as both positive and negative. The negative effects of globalization (in the context of the standard of living of the population) include satisfying apparent needs and the threats resulting from the purchase of global products at the expense of satisfying basic needs. The positive effects include: creation of better conditions for satisfying the needs and expectations of consumers, better access to products of better quality, better developed technology, products with more nutritious value or better utility value, as well as the unification of legislative regulations related to the safety of consumers on the market [Mazurek-Łopacinska, 2003, p. 40].

Symptoms of the globalization process include increasing international economic reliance of entities and integration [Dębska, 2003, p. 17]. It is a very frequent situation that the markets of neighboring countries become integrated with one another. This is affected by cultural similarities, the closeness of supply and sales markets as well as the lower costs of transport. Full integration that is beneficial for everyone requires getting in close contact, compensating the differences in terms of both development and the standard of living of the inhabitants. It means securing the interests of weaker and poorer individuals. European integration was and still is the natural reaction to the processes of globalization.

The main purpose of Poland's integration with the European Union that was essential from the point of view of consumption entities was to ensure stability and prosperity in the country, to improve living standards and, in general, to improve the conditions of existence of the population [Informacje ogólne o Unii Europejskiej, 2018]. The issues related to ensuring a proper level of protecting consumers' rights and interests are of validity here. The Treaty establishing the European Union implies that in order to ensure high security consumer standards, the European Union ought to contribute to protecting the health, security, and economic interests of consumers as well as to promote their rights to have access to information, education and to form organizations in order to protect their own rights [Grzega, 2012, p. 115].

The effects of Poland's integration with the European Union may be assessed from several points of view. Their character may be economic, political, financial, and socio-cultural. From the perspective of considerations regarding the standard of living, what is particularly interesting are the economic and social benefits. The main advantage of integration of an economic nature is participation in the Single European Market and the interrelated free flow of goods, services, capital, and people. Access to various types of structural, regional and other funds ought to be listed among the advantages of Poland's integration with the EU. In the aforementioned context, the increased inflow of investment and new technologies is also not without significance. The main benefits of a social type include the fact that Poland is close to meeting European standards in the sphere of domestic security, decent working conditions 
and environmental protection, which, in general, results in a higher living standard [Konarzewska, 2008, pp. 26-35]. More detailed and at the same time more noticeable benefits of Poland's access to the European Union include: the improvement of the situation on the labor market which was manifested in both reducing the number of unemployed people and in improving the quality of working positions and qualifications of the labor force. Additionally, the homogenous market entailed the benefits related to better availability of goods and services, liberalization of particular markets (e.g. the telecommunication market) and better quality of goods. All of the aforementioned elements created better possibilities for satisfying needs and simultaneously ensured more freedom for consumers [Jakubczak, 2011].

Among the negative (in view of the presented assumptions) effects of Poland's accession to the European Union, the growing prices of consumer goods and services as well as the hazards for national identity and Polish traditions and independence may be mentioned [Rogulska, 2014, p. 11]. With the exception of inflation, those aspects of life have a relatively low impact on the degree of satisfying the needs of entities.

To sum up, it needs to be emphasized that Poland's integration with the European Union resulted from economic transformations related to transformation in Poland. On the other hand, however, it was integration and globalization as external processes that gave direction to the development of transformation in Poland. In general, all these processes are characterized by identical tangents of an economic, social, and political character.

The last among the analyzed conditionings of the standard of living of the population in Poland is the economic crisis. It means the period of considerable difficulties expressed in the rapid decline of economic activity, the situation of a downturn, breakthrough, or change of previously existing tendencies of development of a certain phenomenon [Malinowski, 2008, p. 5]. A crisis as regards the macro conditioning is usually connected with the economic situation of more developed countries and political trends existing there. It explains the scale of proliferation of the crisis initiated in the United States of America in 2008. The crisis was significant, among others, for the situation in Poland, by creating a real hazard for the conditions in which entities on the market function (including consumption entities) [Zachowania polskich konsumentów..., 2011, p. 56].

While analysing the impact of the crisis on shaping the standard of living of the population, it needs to be emphasized that the changes evoked by the crisis are not observed directly after the recognition of its first symptoms but only after a certain time period. Normally, the situation that occurs in the conditions of a crisis and is connected with the improving level of satisfying needs of all the groups or only selected groups' results from the positive inertia evoked by the dynamics of previous periods. The impact of the crisis and the way of perceiving it is different in the case of the particular economic entities and mainly depends on the degree to which they were affected by the crisis situation. In principle, the recognition of the impact of a crisis on 
the standard of living of a population requires much time. An economic crisis may considerably reduce the consumption possibilities of households. The main relation between it and the degree of satisfying needs is as follows: the economic crisis results in the deterioration of the situation on the labor market and/or the income situation of the population, owing to which the level and/or quality of satisfying particular consumption needs are reduced. Naturally, the impact of a crisis is most evident in the case of entities that are directly affected by the crisis situation when, for example, a worse income situation prevents them from satisfying more sophisticated needs, but lets them satisfy only basic needs. This, in turn, creates the premises for feeling less pleasure and satisfaction with life. The largest measurable effect of the economic crisis is a decrease in the degree of satisfying the consumption needs of particular groups. The concern and worry about 'tomorrow' are of validity here. The positive effects of an economic crisis (although it is doubtful whether it is good to mention them) on consumption entities include: more rational management of possessed funds, the reduction of the effects of excessive consumption (its impact on the state of both physical and mental health and on both the natural and social environment), and also reduction of materialistic attitudes, of addiction to shopping, and of a wasteful type of consumption [Grzega, 2012, pp. 117-118].

\section{Conclusions}

All of the aforementioned conditionings have an impact on the standard of living in an objective way. One needs to remember that the group of determinants of an objective character is supplemented by non-economic conditions (e.g. demographic, natural, and spatial) and factors of both a dependent (e.g. income, free time) and independent (e.g. price, supply) economic character, as well as of a non-economic character (e.g. social and occupational ones such as education and the performed profession). Apart from objective variables, the degree of satisfying consumer needs is affected by subjective factors (e.g. habits, customs, motives and attitudes). They modify the reactions of individual entities to the influence of objective factors. However, in view of the presented assumptions, their impact on the standard of living of the population was considered as insignificant.

To conclude, it needs emphasizing that the standard of living of a population is the result of the total comprehensive influence of many various conditions and factors, the basis of which is affected by a certain need. There are many cause-and-effect connections between them and the degree of satisfying the needs of the population The character of these connections remains usually indirect. However, in general, macroeconomic conditionings of the standard of living have a relatively rapid effect on the income of the population, which, in turn, generate consumption expenditures and cause changes in the standard 
of living of the population. Despite the indirect impact of these conditionings, it is necessary to emphasize their 'primeval' character and the fact that they constitute a certain type of economic context for other conditions and factors of not only an economic, but also a non-economic character.

\section{References}

Ashley R., 2008, Growth May Be Good for the Poor, but Decline Is Disastrous. On the Non-Robustness of the Dollar - Kraay Result, "International Review of Economics and Finance" No. 17.

Bałtowski M., Miszewski M., 2006, Transformacja gospodarcza w Polsce, PWN, Warszawa.

Begg D., Fischer S., Dornbusch R., 1999, Makroekonomia, PWE, Warszawa.

Belka M., 2000, Lekcja z polskiej transformacji, "Nowe Życie Gospodarcze”, nr 5.

Berbeka J., 2006, Poziom życia ludności a wzrost gospodarczy w krajach Unii Europejskiej, Wydawnictwo Akademii Ekonomicznej, Kraków.

Bergh J. van den, 2009, The GDP Paradox, "Journal of Economic Psychology", No. 30.

Browning M., Crossley T., 2001, Unemployment Insurance Benefit Levels and Consumption Changes, "Journal of Public Economics", No. 80.

Bywalec Cz., 1991, Wzrost gospodarczy a poziom życia społeczeństwa polskiego, IRWiK, Warszawa.

Bywalec Cz., 2007, Konsumpcja w teorii i praktyce gospodarowania, Wydawnictwo Naukowe PWN, Warszawa.

Bywalec Cz., Rudnicki L., 1999, Podstawy ekonomiki konsumpcji, Wydawnictwo Akademii Ekonomicznej, Kraków.

Chan Yin Fah B., 2010, Living Standard, Living Level and Economic Wellbeing of Older Persons. Similarity and Differences in Measuring These Concepts, "Canadian Social Science", Vol. 6, No. 5.

Davoine L., Erhel C., Guergoat-Lariviere M., 2008, Monitoring Quality in Work. European Employment Strategy Indicators and Beyond, "International Labour Review", No. 147.

Dębska M., 2003, Globalizacja w świetle ekonomii i historii, [w:] Transformacja - integracja-globalizacja, Miklaszewski S. (red.), Instytut Studiów Strategicznych, Kraków.

Dietsch P., 2005, Book Review. The Moral Consequences of Economic Growth, by Benjamin M. Friedman, "Economics and Philosophy", Vol. 25, Issue 01.

Drobnic S., Beham B., Prag P., 2010, Good Job, Good Life? Working Conditions and Quality of Life in Europe, "Social Indicators Research", No. 99.

Eggers A., Gaddy C., Graham C., 2006, Well-Being and Unemployment in Russia in the 1990s. Can Society's Suffering Be Individuals' Solace?, "The Journal of Socio-Economics", Vol. 35, Issue 2. 
Gallie D., 2002, The Quality of Working Life in Welfare Strategy, [in:] Why We Need a New Welfare State, Esping-Andersen G., Gallie D., Hemerijck A., Myles J. (ed.), Oxford University Press, Oxford.

Gallie D., 2007, Production Regimes, Employment Regimes, and the Quality of Work, [in:] Employment Regimes and the Quality of Work, Gallie D. (ed.), Oxford University Press, Oxford.

Grzega U., 2012, Poziom życia ludności w Polsce - determinanty i zróżnicowania, Wydawnictwo Uniwersytetu Ekonomicznego w Katowicach, Katowice.

Informacje ogólne o Unii Europejskiej. Europa, electronic document, access mode: [https://europa.eu/european-union/about-eu_pl, date of entry: 10.04.2018].

Jakóbik W., 2000, Zmiana systemowa a struktura gospodarki w Polsce, WN PWN, Warszawa.

Jakubczak K., Bilans strat i zysków z członkostwa w UE, electronic document, access mode: [http://finanse.wp.pl/kat,98674,title,Bilans-strat-i-zyskow-zczlonkostwa-w-UE,wid,10145916,wiadomosc.html?ticaid=1d254\&_ticrsn=3, date of entry: 5.10.2011].

Kalleberg A., 2009, Precarious Work, Insecure Workers. Employment Relations In Transition, "American Sociological Review", No. 74.

Kenny C., 2005, Why Are We Worried about Income? Nearly Everything that Matters Is Converging, "World Development", Vol. 33, No. 1.

Kołodko G., 1999, Od szoku do terapii. Ekonomia i polityka transformacji, Poltext, Warszawa.

Konarzewska A., 2008, Członkostwo w Unii Europejskiej-korzyści dla Polski. Raport, "Bezpieczeństwo Narodowe", nr I-II/7-8.

Konsument i konsumpcja we wspótczesnej gospodarce 2006, Janoś-Kresło M., Mróz B. (red.), SGH, Warszawa.

Mazurek-Łopacińska K., 2003, Zachowania nabywców i ich konsekwencje marketingowe, PWE, Warszawa.

Larsen V., Sirgy M.J., Wright N.D., 1999, Materialism: The Construct, Measures, Antecedents and Consequences, "Academy of Marketing Studies Journal", Vol. 2, No. 3.

Luszniewicz A., 1972, Statystyka poziomu życia ludności, PWE, Warszawa.

Malinowski A., 2008, Kryzys finansowy a polska gospodarka, "Nowe Życie Gospodarcze", nr 3.

Ng Y., 2003, From Preference to Happiness. Towards a More Complete Welfare Economics, "Social Choice and Welfare", Vol. 20, Issue 3.

Nojszewska E., 1995, Podstawy ekonomii, WSiP, Warszawa.

Pissarides C., 2000, Equilibrium Unemployment Theory (2nd ed.), MIT Press, Cambridge.

Ravallion M., Bailing out the World's Poorest. Policy Research Working Paper 4763.

Rogulska B., 2014, 10 lat członkostwa Polski e Unii Europejskiej, CBOS nr 52, Warsaw. 
Royuela V., Lopez-Tamayo J., Surinach J., 2008, The Institutional vs. the Academic Definition of the Quality of Work Life. What Is the Focus of the European Commission?, "Social Indicators Research", Vol. 86, Issue 3.

Saget C., 2000, Can the Level of Employment Be Explained by GDP Growth in Transition Countries?, "Theory Versus the Quality of Data. Labour", Vol. 14, Issues 4.

Samuelson P., Nordhaus W., 1995, Ekonomia 1, WN PWN, Warszawa.

Słaby T., 2007, Poziom i jakość życia, [w:] Statystyka społeczna, Panek T. (red.), PWE, Warszawa.

Son H., 2010, A Multi-Country Analysis of Achievements and Inequalities in Economic Growth and Standards of Living, "Asian Development Review", Vol. 27, No. 1.

Szarfenberg R., 2012, Czy i kiedy kryzys gospodarczy i wzrost nierówności dochodów sq dobre dla ubogich?, electronic document, access mode: [http://rszarf.ips. uw.edu.pl/pdf/kryzys.pdf, date of entry: 23.02.2012].

Szopa B., 1994, Podział dochodów a poziom życia ludności (na przykładzie Polski), Wydawnictwo Akademii Ekonomicznej, Kraków.

Szulce H., Mruk H., 1989, Instrumenty ksztattowania konsumpcji - sprzężenia i bariery, "Handel Wewnętrzny", nr 3-6.

Schuller B., 2009, Living Standard and Quality of Life in the EU and the Membership Candidate Countries, "Acta Sci. Pol Oeconomia", No. 8 (1).

Tella R. Di, MacCulloch R., Oswald A., 2001, Preferences Over Inflation and Unemployment. Evidence from Surveys of Happiness, "The American Economic Review", Vol. 91, No. 1.

Weil D., 2005, Economic Growth. Pearson Education, Addison-Wesley, Boston. www-wds.worldbank.org/external/default/WDSContentServer/IW3P/IB/20 08/12/16/000158349_20081216092058/Rendered/INDEX/WPS4763.txt [date of entry: 24.02.2012].

Zachowania polskich konsumentów w warunkach kryzysu gospodarczego, 2011, Kieżel E., Smyczek S. (red.), Placet, Warszawa. 